\title{
Technical Note: A trace gas climatology derived from the Atmospheric Chemistry Experiment Fourier Transform Spectrometer (ACE-FTS) data set
}

\author{
A. Jones ${ }^{1}$, K. A. Walker ${ }^{1,2}$, J. J. Jin ${ }^{3}$, J. R. Taylor ${ }^{4,5}$, C. D. Boone ${ }^{2}$, P. F. Bernath ${ }^{6,7}$, S. Brohede ${ }^{8}$, G. L. Manney ${ }^{3,9}$, \\ S. McLeod $^{2}$, R. Hughes ${ }^{2}$, and W. H. Daffer ${ }^{3}$ \\ ${ }^{1}$ Department of Physics, University of Toronto, Toronto, Canada \\ ${ }^{2}$ Department of Chemistry, University of Waterloo, Waterloo, Ontario, Canada \\ ${ }^{3}$ Jet Propulsion Laboratory, California Institute of Technology, Pasadena, CA, USA \\ ${ }^{4}$ National Center for Atmospheric Research, Boulder, CO, USA \\ ${ }^{5}$ National Ecological Observatory Network, Boulder, CO, USA \\ ${ }^{6}$ Department of Chemistry and Biochemistry, Old Dominion University, Norfolk, Virginia, USA \\ ${ }^{7}$ Department of Chemistry, University of York, Heslington, York, UK \\ ${ }^{8}$ Department of Radio and Space Science, Chalmers University of Technology, Gothenburg, Sweden \\ ${ }^{9}$ New Mexico Institute of Mining and Technology, Socorro, New Mexico, USA
}

Correspondence to: K. A. Walker (kwalker@atmosp.physics.utoronto.ca)

Received: 20 July 2011 - Published in Atmos. Chem. Phys. Discuss.: 7 November 2011

Revised: 25 April 2012 - Accepted: 18 May 2012 - Published: 14 June 2012

\begin{abstract}
The Atmospheric Chemistry Experiment-Fourier Transform Spectrometer (ACE-FTS) aboard the Canadian satellite SCISAT (launched in August 2003) was designed to investigate the composition of the upper troposphere, stratosphere, and mesosphere. ACE-FTS utilizes solar occultation to measure temperature and pressure as well as vertical profiles of over thirty chemical species including $\mathrm{O}_{3}, \mathrm{H}_{2} \mathrm{O}, \mathrm{CH}_{4}$, $\mathrm{N}_{2} \mathrm{O}, \mathrm{CO}, \mathrm{NO}, \mathrm{NO}_{2}, \mathrm{~N}_{2} \mathrm{O}_{5}, \mathrm{HNO}_{3}, \mathrm{HCl}, \mathrm{ClONO}_{2}, \mathrm{CCl}_{3} \mathrm{~F}$, $\mathrm{CCl}_{2} \mathrm{~F}_{2}$, and $\mathrm{HF}$. Global coverage for each species is obtained approximately over a three month period and measurements are made with a vertical resolution of typically $3-4 \mathrm{~km}$. A quality-controlled climatology has been created for each of these 14 baseline species, where individual profiles are averaged over the period of February 2004 to February 2009. Measurements used are from the ACE-FTS version 2.2 data set including updates for $\mathrm{O}_{3}$ and $\mathrm{N}_{2} \mathrm{O}_{5}$. The climatological fields are provided on a monthly and three-monthly basis (DJF, MAM, JJA, SON) at 5 degree latitude and equivalent latitude spacing and on 28 pressure surfaces (26 of which are defined by the Stratospheric Processes And their Role in Climate (SPARC) Chemistry-Climate Model Validation Activity). The ACE-FTS climatological data set is available through the ACE website.
\end{abstract}

\section{Introduction}

Coupled Chemistry-Climate models (CCMs) and General Circulation Models (GCMs) are widely used by the scientific community to improve our understanding of the atmosphere. In the middle atmosphere, such models play a key role in predictions of stratospheric ozone loss, which has been a main concern for more than two decades. In addition, atmospheric climate models are useful in investigating atmospheric responses to fluctuations in solar intensity, to changes in key greenhouse gases (e.g. carbon dioxide), to volcanic activity, and to changes in other radiative forcing parameters, which collectively are significant processes in controling climate change.

The CCM Validation (CCMVal) Activity, which is part of the World Climate Research Program's (WCRP) Stratospheric Process And their Role in Climate (SPARC) project, was designed to intercompare stratosphere-resolving CCMs by examining their ability to represent the atmosphere and its processes and properties such as chemistry, dynamics, transport, and radiation (SPARC CCMVal, 2010). Such an assessment exercise is needed to estimate the level of model uncertainty in order to ascertain and improve model performance.

Published by Copernicus Publications on behalf of the European Geosciences Union. 
This may be done by comparing models to each other, but also needs to be accompanied by comparing model simulations to well-characterized trace gas observations, which are often provided in the form of a climatological average. Furthermore, climatological data can provide information about what assumptions should be made concerning initial conditions and input parameterizations and can be used to constrain various model parameters as necessary. In addition, climatological data can be used for analysis of tracer transport and of inter-annual variability, leading to a better understanding of the dynamical and chemical processes involved (e.g. Randel et al., 1998).

Observational climatology data is widely used and is a comprehensive way of representing data over specific periods of time. There are various long-term climatological products available based on the measurements of the middle atmosphere that have been reported over the last $14 \mathrm{yr}$. The earliest ozone climatology was compiled by Fortuin and Kelder (1998) using an amalgamation of data provided by ozonesondes and the Solar Back-scatter UltraViolet (SBUV) instrument for the period of 1980-1991. Randel et al. (1998) produced $\mathrm{CH}_{4}$ and $\mathrm{H}_{2} \mathrm{O}$ climatologies using data collected during 1991-1997 by the Upper Atmospheric Research Satellite (UARS) Halogen Occultation Experiment (HALOE) instrument (Russell et al., 1993), while Beaver and Russell produced $\mathrm{HCl}$ and $\mathrm{HF}$ climatologies for the first 4.5 years of the HALOE mission (1998). A water vapour climatology was produced by Chiou et al. (1997) using data from the Stratospheric Aerosol and Gas Experiment SAGE II instrument. A comprehensive HALOE climatology product was compiled by Grooß and Russell (2005) for $\mathrm{O}_{3}, \mathrm{CH}_{4}, \mathrm{H}_{2} \mathrm{O}, \mathrm{HF}, \mathrm{HCl}$, and $\mathrm{NO}_{\mathrm{x}}$ using data from 19912002. McPeters et al. (2007) used a similar technique to Fortuin and Kelder to compile an ozone climatology for 1988-2002 using data from ozonesondes and the SAGE II and UARS Microwave Limb Sounder (UARS-MLS) satellite instruments. The UARS reference atmosphere project provides climatologies for some key atmospheric species utilizing measurements from various UARS instruments during their lifetime of 1991-2005 (http://umpgal.gsfc.nasa.gov/). Hoffmann et al. (2008) produced a $\mathrm{CCl}_{3} \mathrm{~F}$ (CFC-11) upper troposphere/lower stratosphere climatology for 20022004 using data from the Michelson Interferometer for Passive Atmospheric Sounding (MIPAS) instrument on Envisat. The Odin Sub-Millimetre Radiometer (Odin-SMR) $\mathrm{HNO}_{3}$ and Odin Optical Spectrograph and InfraRed Imager System (Odin-OSIRIS) $\mathrm{NO}_{2}$ data were combined with a chemical box model to produce an $\mathrm{NO}_{\mathrm{y}}$ climatology for 2002-2006

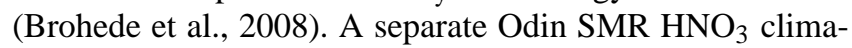
tology has also been produced for the period 2001-2009 (Urban et al., 2009). Recently, Jones et al. (2011) created an $\mathrm{NO}_{\mathrm{y}}$ climatology using 2004-2009 measurements from the Atmospheric Chemistry Experiment Fourier Transform Spectrometer (ACE-FTS) following the methodology described herein.
Here, we present a climatology that utilizes data from ACE-FTS between 2004 and 2009. This data set is intended to complement the existing climatologies from HALOE and other instruments (as described above) by providing information for a larger number of species (fourteen in total) in a consistent data set. This will provide a source of data for model intercomparison studies and other atmospheric research projects. For example, the range of chlorine- and nitrogen-containing trace gases measured by ACE-FTS can provide information about how these species are partitioned within families. In the following section, we give a summary of the ACE mission as well as introduce the main species for which the climatologies are produced, including a summary of the relevant validation results for each species. Section 3 describes the methodology used to produce the climatologies. Finally, Sect. 4 illustrates selected results for the climatological products.

\section{Description of ACE-FTS and its data products}

The ACE mission is on-board the SCISAT satellite which was put into orbit on 12 August 2003. SCISAT is a Canadianled satellite mission, which carries two main instruments to study atmospheric composition: the ACE Fourier Transform Spectrometer (ACE-FTS) (Bernath et al., 2005), and the Measurement of Aerosol Extinction in the Stratosphere and Troposphere Retrieved by Occultation (ACE-MAESTRO) (McElroy et al., 2007). Measurements taken by both of these instruments utilize solar occultation geometry, making up to 15 sunset and 15 sunrise measurements per day. In addition to these instruments, there is a two channel visible/nearinfrared imager (ACE-IMAGER) that yields extinction profiles at $0.525 \mu \mathrm{m}$ and $1.02 \mu \mathrm{m}$ (Gilbert et al., 2007). The SCISAT satellite is in a circular orbit at $650 \mathrm{~km}$ altitude with a 74 degree inclination angle to the equator. It has an annually repeating pattern of measurement latitudes (as shown in Fig. 1). During a 12 month period, the ACE orbit allows global measurements to be made from $85^{\circ} \mathrm{S}$ to $85^{\circ} \mathrm{N}$ with all latitudes covered during each three-month season.

The ACE-FTS measurements provide vertical profiles of more than 30 atmospheric species, temperature, and pressure from spectra measured between 750 and $4400 \mathrm{~cm}^{-1}$ ( 2.2 to $13 \mu \mathrm{m})$ at a resolution of $0.02 \mathrm{~cm}^{-1}$ (Bernath et al., 2005). Information about the processing of the measured spectra is provided by Boone et al. (2005). Briefly, the retrieval process uses a two step sequence. Firstly, both atmospheric pressure and temperature are retrieved using microwindows containing $\mathrm{CO}_{2}$ spectral lines. Then the pressure and temperature information are used with line parameters from the HITRAN database (Rothman et al., 2005) to retrieve vertical profiles of volume mixing ratio (VMR) for each species using a nonlinear least squares fit approach. It should be noted that this global fitting technique does not utilize a priori information. Atmospheric profiles are provided on both the measurement 


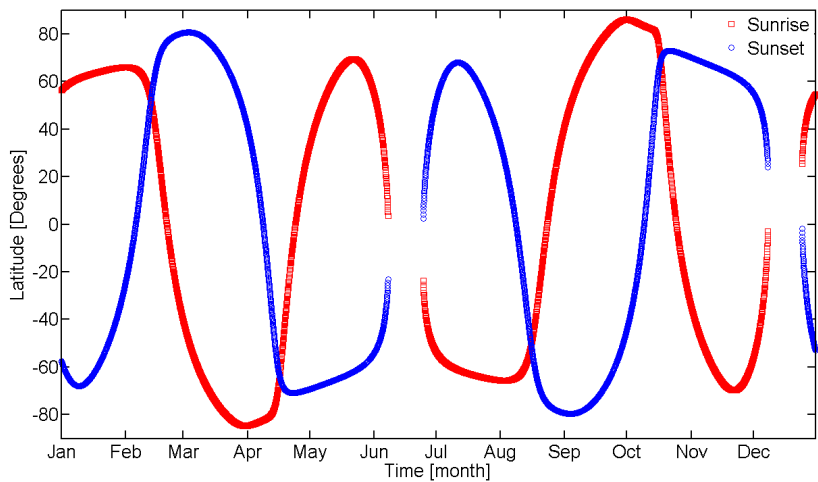

Fig. 1. Latitude versus time of ACE-FTS observations for one year. The SCISAT satellite maintains an annually repeating pattern of measurement latitudes.

grid (tangent height) and are also interpolated onto a 1-km grid using a piecewise quadratic method. For this project, the profiles on the measurement grid have been used.

The 14 baseline atmospheric species measured by ACEFTS are $\mathrm{O}_{3}, \mathrm{H}_{2} \mathrm{O}, \mathrm{HCl}, \mathrm{CCl}_{3} \mathrm{~F}, \mathrm{CCl}_{2} \mathrm{~F}_{2}, \mathrm{CH}_{4}, \mathrm{HF}, \mathrm{N}_{2} \mathrm{O}$, $\mathrm{CO}, \mathrm{NO}, \mathrm{NO}_{2}, \mathrm{HNO}_{3}, \mathrm{ClONO}_{2}$, and $\mathrm{N}_{2} \mathrm{O}_{5}$. We use version 2.2 of ACE-FTS retrievals (including updates for $\mathrm{O}_{3}$ and $\mathrm{N}_{2} \mathrm{O}_{5}$ ), all of which have been validated. At present, no error budget estimates have been made for this data set. The following are descriptions of each species with a short summary of the validation results, highlighting the biases between ACE-FTS and other atmospheric profile data sets. For a more comprehensive description for each species, the reader is directed to the relevant article. The referenced articles are part of the ACE validation results special issue (http://www.atmos-chem-phys.net/ special_issue114.html). For each species, the title of the subsection contains the relevant validation reference and the typical retrieval altitude range.

\section{$2.1 O_{3}-$ Dupuy et al. (2009) $(5-95 \mathrm{~km})$}

This work uses the version 2.2 ozone update. For this version, there is a small positive bias, between ACE-FTS and correlative satellite and ozonesonde measurements, typically of +1 to $+8 \%$ in the stratosphere $(16-44 \mathrm{~km})$. Above $45 \mathrm{~km}$, ACE-FTS ozone values are significantly larger than the comparison instruments by up to $+40 \%(+20 \%$ on average). These comparisons were made with solar occultation instruments, such as HALOE (v19), SAGE II (v6.2), SAGE III (v3.0), and POAM III (v4.0), and other satellite measurements, including GOMOS (IPF v5.0), SCIAMACHY (IUP v1.63), Aura-MLS (v2.2), and MIPAS (ESA v4.62, ML2PP/5, V3O_O3_7). No significant differences were found in the biases for sunrise and sunset occultations.

\section{$2.2 \quad \mathrm{H}_{2} \mathrm{O}$ - Carleer et al. (2008) $(5-89 \mathrm{~km})$}

Coincident satellite measurements from SAGE II (v6.2), HALOE (v19), MIPAS (v13 IMK-IAA), and Odin SMR (v2.1) have been compared with ACE-FTS $\mathrm{H}_{2} \mathrm{O}$. In these comparisons, ACE-FTS has a small positive bias of 3-10\% between 15 and $90 \mathrm{~km}$. In comparisons with POAM III (v4.0), there is a negative bias for ACE-FTS between 15 and $39 \mathrm{~km}$ that is consistent with earlier POAM III comparisons.

\section{3 $\mathrm{HCl}$ - Mahieu et al. (2008) $(8-57 \mathrm{~km})$}

Comparisons of coincident measurements from ACE-FTS and Aura MLS (v2.2) show agreement better than $5 \%$ between 100 and $0.1 \mathrm{hPa}(\sim 16-60 \mathrm{~km})$. Comparisons to the HALOE instrument (v19) show that there is a bias between coincident measurements of $+10-15 \%$ in the stratosphere (approximately $20-50 \mathrm{~km}$ ). A similar bias is seen in comparisons between Aura MLS and HALOE (Froidevaux et al., 2008). Furthermore, a comparison of an ACE-FTS zonal mean profile and profiles from the balloon-borne MkIV during the autumn of 2003, 2004 and 2005 around $35^{\circ} \mathrm{N}$ yields agreement of better than $\pm 7 \%$ up to $20 \mathrm{~km}$.

\section{4 $\mathrm{CCl}_{3} \mathrm{~F}(\mathrm{CFC}-11)$ - Mahieu et al. (2008) $(5-22 \mathrm{~km})$}

There were limited CFC satellite data available for the Mahieu et al. (2008) validation analysis. Thus comparisons were made with balloon-borne measurements from FIRS-2 and MkIV. The differences between individual ACE-FTS and FIRS-2 profiles are typically $-10 \%$ from 12 to $16 \mathrm{~km}$, where the ACE-FTS VMRs are slightly smaller than FIRS-2. An ACE-FTS zonal mean profile is systematically smaller than coincident MkIV profiles by typically $-10 \%$ above $12 \mathrm{~km}$ and up to $-20 \%$ below $12 \mathrm{~km}$.

\section{$2.5 \mathrm{CCl}_{2} \mathrm{~F}_{2}(\mathrm{CFC}-12)-$ Mahieu et al. (2008) $(6-28 \mathrm{~km})$}

As was done for $\mathrm{CCl}_{3} \mathrm{~F}$, ACE-FTS $\mathrm{CCl}_{2} \mathrm{~F}_{2}$ profiles were compared to FIRS-2 and MkIV balloon profiles. ACE-FTS measurements were averaged to create a zonal mean profile to compare with the MkIV 2004 and 2005 profiles. These comparisons show a maximum bias of $-10 \%$ between 10 and $28 \mathrm{~km}$. The comparison of individual profiles from ACEFTS and FIRS- 2 show large systematic biases of $\pm 50 \%$ between 12 and $21 \mathrm{~km}$. However, between 17 and $24 \mathrm{~km}$, these differences are within the uncertainty of the FIRS-2 measurement.

\section{6 $\mathrm{CH}_{4}-$ De Mazière et al. (2008) $(5-62 \mathrm{~km})$}

The bias between ACE-FTS and correlative HALOE (v19) profiles is approximately $+5 \%$ up to $35 \mathrm{~km}$ and increases at higher altitudes $(40-60 \mathrm{~km})$ to between +10 and $+15 \%$. In comparisons with MIPAS (ESA v4.62), ACE-FTS is typically lower than MIPAS with differences up to $\pm 12 \%$ up 
to $60 \mathrm{~km}$. A comparison with a January 2006 high-latitude profile from the balloon-borne SPIRALE instrument showed that there is a small bias between ACE-FTS and SPIRALE that is smaller than $\pm 10 \%$ between 15 and $24 \mathrm{~km}$.

\subsection{HF - Mahieu et al. (2008) (10-50 km)}

As was found for $\mathrm{HCl}$, coincident ACE-FTS and HALOE (v19) measurements show an ACE-FTS bias of typically +5 $20 \%$ between 15 and $49 \mathrm{~km}$. Additionally, a comparison of a zonal average ACE-FTS profile (as no direct comparisons were found) to the 2004 and 2005 MkIV balloon profiles agree better than $\pm 10 \%$ above $19 \mathrm{~km}$.

\section{$2.8 \quad \mathrm{~N}_{2} \mathrm{O}-$ Strong et al. $(2008)(5-60 \mathrm{~km})$}

ACE-FTS $\mathrm{N}_{2} \mathrm{O}$ profiles were compared with measurements from Odin SMR (v2.1), Aura MLS (v2.2) and MIPAS (ESA, v4.62 and IMK-IAA, v3.0). The relative differences for these data sets are within $\pm 15 \%$ between 6 and $30 \mathrm{~km}$, except for MIPAS near $30 \mathrm{~km}$ where the differences are as large as $-22.5 \%$. Between 30 and $60 \mathrm{~km}$, the absolute differences for the satellite comparisons typically range from -2 to $+1 \mathrm{ppbv}$. Relative differences are not given because the $\mathrm{N}_{2} \mathrm{O}$ VMR is quite small over this altitude range.

\subsection{CO - Clerbaux et al. (2008) $(5-105 \mathrm{~km})$}

The agreement with correlative satellite limb measurements, including MIPAS (version 9.0) and Odin SMR (v2.1), is typically better than $30 \%$ from 20 to $100 \mathrm{~km}$. Larger differences were found in comparisons with Aura MLS because there was greater noise in the MLS profiles than in the ACE-FTS ones. Between 6 and $14 \mathrm{~km}$, agreement of $\pm 2 \%$ or better was found in comparisons with nadir measurements by MOPITT and TES. For these comparisons, the ACE-FTS profiles were smoothed using the averaging kernels of the lower resolution instruments.

\subsection{NO - Kerzenmacher et al. (2008) (12-105 km)}

Comparisons made to the HALOE (v19) data set show relative differences that are less than $\pm 20 \%$ below $60 \mathrm{~km}$ and typically better than $\pm 8 \%$ between $22 \mathrm{~km}$ and $60 \mathrm{~km}$. Between 60 and $90 \mathrm{~km}$, ACE-FTS is biased low compared to HALOE $(\sim 80 \%)$, although the one sigma uncertainty in the systematic biases is often zero, implying that statistical differences are not significant. ACE-FTS also shows a typical $+10 \%$ bias compared to HALOE from to $93 \mathrm{~km}$ to $105 \mathrm{~km}$.

\section{$2.11 \mathrm{NO}_{2}-$ Kerzenmacher et al. (2008) $(12-105 \mathrm{~km})$}

The relative differences from comparisons of ACE-FTS to SAGE II (v6.2), HALOE (v19), and MIPAS (IMK-IAA, v3.0) are typically better than $\pm 20 \%$ throughout the stratosphere $(\sim 20-50 \mathrm{~km})$, with slightly better than $10 \%$ system- atic bias resulting from ACE-FTS coincidences with SCIAMACHY (v2.0, occultation and nadir), GOMOS (IPF 5.0), and SAGE III (v3.0). Comparisons with Odin OSIRIS (v3.0) yield a relative difference of typically less than $6 \%$ between 14 and $24 \mathrm{~km}$ and $13 \%$ above $25 \mathrm{~km}$. ACE-FTS exhibits a consistent low bias compared to MIPAS (ESA, v4.62) of $-8 \%$ and $-45 \%$ in the lower and upper stratosphere respectively. This study used a chemical box model (McLinden et al., 2000; McLinden 2006) for comparisons to GOMOS and OSIRIS so as to account for the strong diurnal effect of $\mathrm{NO}_{2}$. Here, scale factors were calculated to re-scale GOMOS and OSIRIS $\mathrm{NO}_{2}$ measurements to the local solar times (LSTs) of the ACE-FTS coincidences.

\section{$2.12 \mathrm{HNO}_{3}-$ Wolff et al. (2008) (5-37 km)}

The agreement between coincident measurements from Odin SMR (v2.0), MIPAS (ESA v4.62, IMK-IAA v8.0), and MLS (v2.2) is typically better than $20 \%$ (and often within 10\%) for the overlapping altitude ranges of each instrument.

\section{$2.13 \mathrm{ClONO}_{2}-$ Wolff et al. (2008) $(5-37 \mathrm{~km})$}

Comparisons with coincident MIPAS (IMK-IAA v11.0) data show agreement to better than $\pm 1 \%$ from $16-27 \mathrm{~km}$ and within $+14 \%$ from $27-34 \mathrm{~km}$. As $\mathrm{ClONO}_{2}$ has some diurnal variation, these comparisons required the use of a chemistry transport model (Kouker et al., 1999) to transform the MIPAS observations to the time and location of the ACE-FTS occultations.

\section{$2.14 \mathrm{~N}_{2} \mathrm{O}_{5}-$ Wolff et al. $(2008)(5-37 \mathrm{~km})$}

Similar to the ozone validation, this work uses the ACEFTS v2.2 $\mathrm{N}_{2} \mathrm{O}_{5}$ update. Below $27 \mathrm{~km}$, relative differences between ACE-FTS and MIPAS (IMK-IAA v9.0) are typically better than $-10 \%$ and $-27 \%$ during daytime and nighttime, respectively. To account for the strong $\mathrm{N}_{2} \mathrm{O}_{5}$ diurnal variation, the same chemistry transport model was employed as was used for the $\mathrm{ClONO}_{2}$ study.

\section{Methodology}

In order to discuss the production of a climatology, it is first useful to provide a definition. Simply put, a climatology is the average state of an atmospheric parameter over a given time period with respect to altitude and geolocation coordinates. Typically, a climatology is provided as a function of altitude (or pressure), latitude (or equivalent latitude) and time (month or season).

\subsection{ACE climatology grid description}

For the vertical coordinate, we utilize atmospheric pressure. We use 28 pressure surfaces, 26 of which are defined by the CCMVal activity: 300, 250, 200, 170, 150, 130, 115, 100, 
$90,80,70,50,30,20,15,10,7,5,3,2,1.5,1,0.5,0.3$, 0.2, $0.1 \mathrm{hPa}$ (SPARC CCMVal, 2010). The other two pressure levels are added in the upper stratosphere and lower mesosphere, namely, 0.7 and $0.15 \mathrm{hPa}$. These pressure levels are the centres of each bin. The limits of each bin are calculated to be equidistant from the adjacent centres in log pressure. The horizontal coordinate is divided into 5 degree intervals from $90^{\circ} \mathrm{S}$ to $90^{\circ} \mathrm{N}$ (e.g. the $90^{\circ} \mathrm{S}$ to $85^{\circ} \mathrm{S}$ interval is labeled as $87.5^{\circ} \mathrm{S}$ ).

\subsection{Filling the grid}

The ACE-FTS climatologies are made for $\mathrm{O}_{3}, \mathrm{H}_{2} \mathrm{O}, \mathrm{CH}_{4}$, $\mathrm{N}_{2} \mathrm{O}, \mathrm{CO}, \mathrm{NO}, \mathrm{NO}_{2}, \mathrm{~N}_{2} \mathrm{O}_{5}, \mathrm{HNO}_{3}, \mathrm{HCl}, \mathrm{ClONO}_{2}, \mathrm{CCl}_{3} \mathrm{~F}$, $\mathrm{CCl}_{2} \mathrm{~F}_{2}$, and $\mathrm{HF}$ on a monthly and three-month combined basis using the set of more than 19000 occultation measurements obtained between late February 2004 and late February 2009. The yearly latitude coverage of the ACE measurements is shown in Fig. 1. ACE obtains global latitude coverage over a period of approximately three months. This means that for any given month there will be gaps in the climatology as certain latitudes will not be measured due to the nature of the SCISAT orbit. In addition to making climatologies arranged by latitude, we also compile climatologies on an equivalent latitude grid. Equivalent latitude is a vortexcentred coordinate system based on the area enclosed by potential vorticity contours (Butchart and Remsberg, 1986). This is a useful parameter since, in addition to insuring that data averaged together are from similar air masses, it also allows for a broader coverage to be attained due to the variations in potential vorticity at a given latitude, thus helping to fill some of the gaps that would occur in the latitude climatology fields. For each ACE-FTS profile, equivalent latitude, as a function of altitude, is available as part of the suite of "derived meteorological products" (DMPs) as described in Manney et al. (2007). To calculate these DMPs, the GEOS5 meteorological fields (Rienecker et al., 2008) are interpolated to the location and time of the ACE-FTS measurement (Manney et al., 2007).

Some of the species measured by ACE-FTS have diurnal variations (such as $\mathrm{NO}, \mathrm{NO}_{2}, \mathrm{HNO}_{3}, \mathrm{ClONO}_{2}$, and $\mathrm{N}_{2} \mathrm{O}_{5}$ ). In order to account for this, we consider the local solar time (LST) of the measurements, such that separate climatologies are produced for AM (before local solar noon) and PM (after local solar noon) in addition to a climatology based on all occultations $(\mathrm{AM}+\mathrm{PM})$. LST is calculated by considering the universal time (UTC) and the longitude $(\phi$, defined as $-180^{\circ}$ to $+180^{\circ}$ ) of each occultation at the ACE-FTS $30 \mathrm{~km}$ reference tangent point as was done in Nassar et al. (2006),

$\mathrm{LST}=\mathrm{UTC}+(24 / 360) \phi$.

For consistency, we apply this method to all 14 species to provide AM, PM and AM + PM combined climatologies.

During the process of sorting individual measurements into the relevant grid bin for a given month, various crite- ria are applied. Firstly, occultation profiles that are known to have issues are disregarded (e.g. those labeled "Do Not Use" in the Data Issues List which is provided from the ACE website: https://databace.uwaterloo.ca/validation/data issues_table.php). Unrealistically large or small VMRs are then removed, for example $\mathrm{O}_{3}$ values that were less than -2 ppmv or greater than +20 ppmv. Overall, this has removed data from less than 20 profiles from the data set. Thirdly, any measurement for which the absolute fitting uncertainty is larger than retrieved value is ignored and similarly, any measurement with an absolute fitting uncertainty that is smaller than $0.01 \%$ of the retrieved value is also ignored. A related exclusion method was used in the HALOE climatology (Grooß and Russell, 2005) and this particular filtering method has been employed in other ACE studies (e.g. Dupuy et al., 2009).

Final filtering is performed by using a statistical technique, namely the median absolute deviation (or MAD). Since a climatology is the most probable state of the atmosphere for a given time and location, we must be able to remove observations that are considered non-representative of the most probable state. MAD is a measure of statistical dispersion and it is a powerful filtering method used to remove outliers from a sample of data (Huber, 2004). It is often preferred over the use of the standard deviation and mean of a data set as the median is considered more robust and less affected by extreme observations. Because the standard deviation is dependent upon the square of the difference from the mean value, it ensures that large deviations are heavily weighted in this calculation. When using the MAD, the magnitude of the difference between the median and a given value is less of an issue for the outlying values because of the linear relationship. Toohey et al. (2010) have found the MAD to be an effective method of reducing the impact of outliers when using measurements from ACE-FTS. The expression for the MAD is given in Eq. (2),

$\operatorname{MAD}_{n}=\operatorname{median}\left(\left|x_{i}-M_{n}\right|\right)$

Here, MAD is calculated by finding the median of the absolute deviation between observations $x_{i}$ and the median, $M$, of $n$ data points. Figure 2 illustrates the relationship between the standard deviation and MAD of a data set within a Gaussian distribution of values. In this work, we use 3 MADs to filter the data as it is approximately 2 sigma. This means that for a Gaussian distribution approximately $5 \%$ of all observations would be considered outliers and thus removed. Figure 3 shows an example of all ACE-FTS ozone observations (before and after 3 MAD filtering) for the latitude bin centered at $67.5^{\circ} \mathrm{S}$ during the month of January (2004-2009). The observations here have been sorted into the relevant pressure bins defined above. Also shown is the median profile based upon these values as well as a surrounding envelope which designates the 3 MAD range. Thus, values that are outside the envelope (red dots) are considered non-representative, 


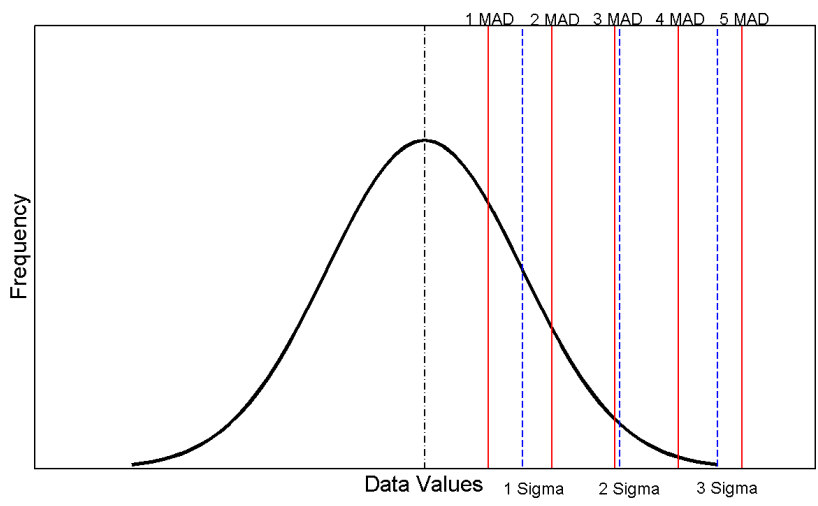

Fig. 2. A random set of values can be characterized by a normal distribution curve (black thick line). The thick black dot-dash line represents the equal mean and median values for the normally distributed data. The MAD values are represented by the red solid lines, while the blue dashed lines characterize the standard deviations.

i.e. outliers, and are therefore disregarded. For this particular case, $95 \%$ of the observations (blue stars) are retained. Since experimental data sets are not always entirely Gaussian in nature, more than $5 \%$ of all observations will be removed by 3 MAD filtering in most cases. We find this number to be typically $5-10 \%$ of the total population for each bin, but this still allows the data set to be representative of the atmospheric state.

\subsection{Calculating the climatological mean values}

After applying the filtering methods described above, the remaining measurements in each bin are used to produce the climatologies. The mean value for a given bin, either latitude or equivalent latitude range, will be included in the climatology if there are five or more data points used in the calculation. This provides a level of statistical robustness in the climatological values. In making the climatologies, we calculate the weighted mean value within each bin using the inverse of the absolute fitting uncertainty (rather than the inverse variance) as the weighting factor. Hence, observations with large fitting uncertainties are weighted less than those with smaller fitting uncertainties. This method is used to take the quality of the retrieved data into account when calculating the climatological mean. This technique is similar to that used by Grooß and Russell (2005) in their HALOE climatology, where they weighted by the inverse of the accuracy to account for the quality of the data in their calculations.

Climatological VMR values are calculated by month and combined three-monthly climatologies are also produced, namely, December-January-February (DJF), MarchApril-May (MAM), June-July-August (JJA), and SeptemberOctober-November (SON). Note that these three-month combinations are not strictly a seasonal average. Due to the

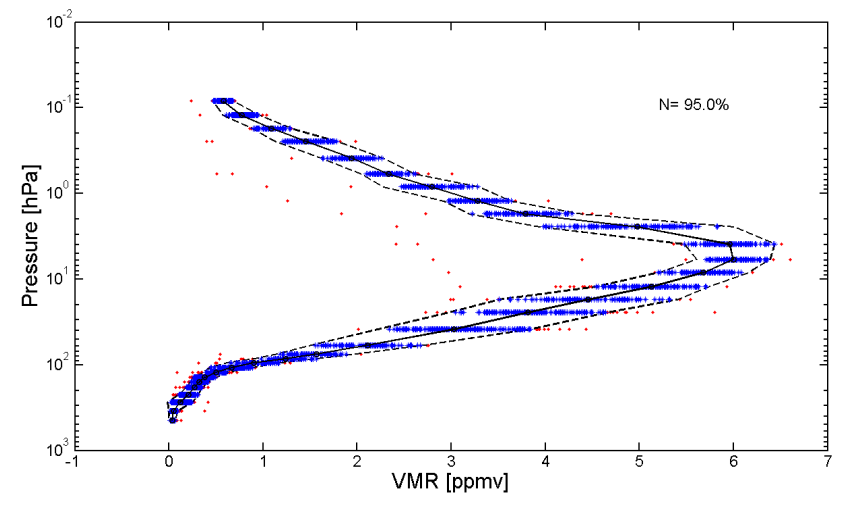

Fig. 3. Example of January $\mathrm{O}_{3}$ data $\left(67.5^{\circ} \mathrm{S}\right.$ bin $)$ and how outliers are removed using MAD filtering. Red dots are data that are deemed non-representative $(\sim 5 \%)$ and are thus rejected. Solid black line is the median of all observations, while the dashed line is the \pm 3 MAD envelope. $N$ represents the percentage of retained measurements after 3 MAD filtering ( $\sim 95 \%)$.

SCISAT satellite's orbit only certain latitudes/equivalent latitudes are measured for any given month. For some species, this can result in apparent discontinuities in the climatological values in regions where there are sharp gradients in VMR.

\subsection{Additional information}

To complement the climatological VMR data, we have included a suite of information to aid in the interpretation of the data set comparison. These extra data are provided as part of the climatological data products and describe the data in each bin. These data are provided on the same pressure/latitude grid (or pressure/equivalent latitude grid) as the VMR information. Firstly, the standard deviation for each grid bin for each species is supplied, which will help characterize the degree of variation on a monthly (or three-monthly) basis. We also provide the number of observations for every grid bin, thus offering a measure of the level of statistical robustness for a given climatological value. LST information is also stored for each grid bin. These include the mean, standard deviation, median, maximum, and minimum of the LSTs for the measurements that are used to calculate the VMR climatological value in each grid bin.

\subsection{Data formats and availability}

The ACE-FTS climatological data products are available in ASCII and NetCDF formats. These products are available as a supplement to this paper. In addition, updates to these data products (to include additional years of data) will be made available via the ACE website (http://www.ace.uwaterloo.ca/ climatology.html). The additional information is also available through the ACE website and can be provided on request (MATLAB format only). 

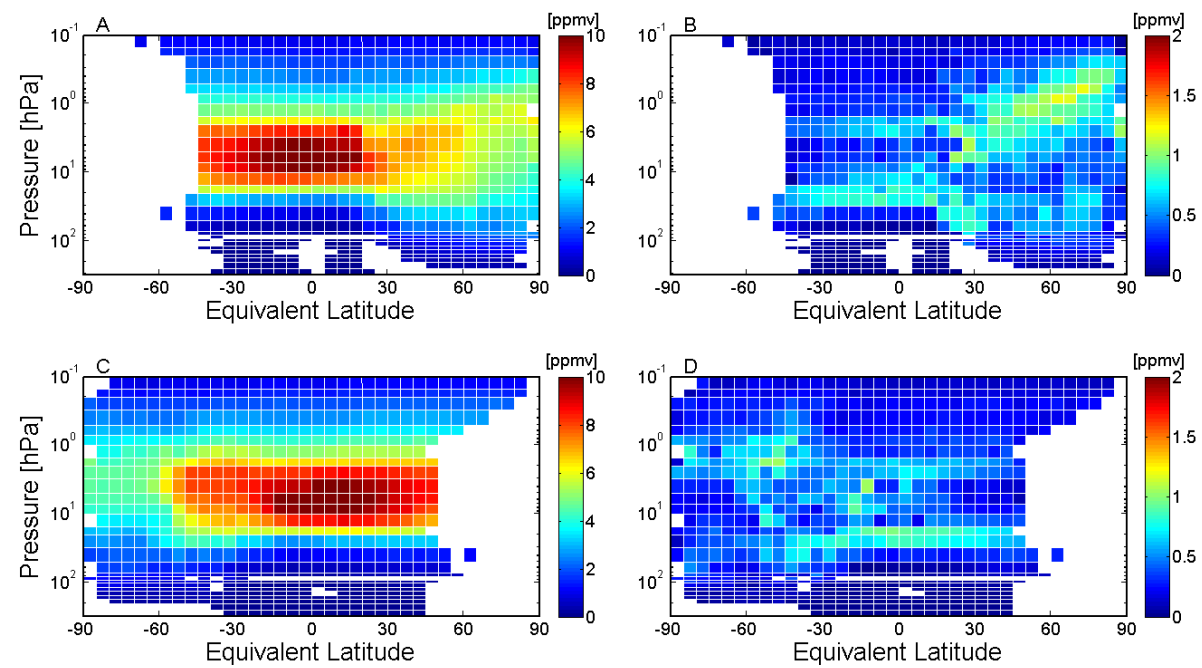

Fig. 4. ACE-FTS $\mathrm{O}_{3}$ climatology for February (A) and August (C). Also shown is the one standard deviation of the $\mathrm{O}_{3}$ climatology for February (B) and August (D). The gaps in the data are either where there were no observations made (for example, the summer hemisphere pole for the months considered here) or where there are less than 5 observations for a given bin.

\section{Results}

The following highlights some results from the ACE-FTS climatologies. For brevity, we have chosen to present six of the fourteen baseline species. We have selected two radiatively important species $\left(\mathrm{O}_{3}\right.$ and $\left.\mathrm{H}_{2} \mathrm{O}\right)$, examples of chlorine reservoir and source species $\left(\mathrm{HCl}\right.$ and $\left.\mathrm{CCl}_{3} \mathrm{~F}\right)$ and active nitrogen species $\left(\mathrm{NO}\right.$ and $\mathrm{NO}_{2}$ ) for illustration. For $\mathrm{O}_{3}, \mathrm{H}_{2} \mathrm{O}, \mathrm{HCl}$, and $\mathrm{CCl}_{3} \mathrm{~F}$, we provide examples of the February and August climatological VMR fields, obtained by combining the $\mathrm{AM}+\mathrm{PM}$ measurements. For $\mathrm{NO}$ and $\mathrm{NO}_{2}$, species which have strong diurnal variations, we show AM and PM climatologies separately. Also, some examples of the three-month combined climatologies are shown. In all cases, we show the climatology calculated in terms of pressure as a function of equivalent latitude.

To ascertain a level of confidence, each of the 14 climatological products have been compared to various other climatological data sets. $\mathrm{O}_{3}, \mathrm{HCl}, \mathrm{CH}_{4}, \mathrm{H}_{2} \mathrm{O}$, and $\mathrm{HF}$ have been compared directly to the HALOE climatology (Grooß et al., 2005), while the other species have been compared to zonal mean fields calculated from the outputs from a CCM (the Canadian Middle Atmospheric Model (CMAM), Scinocca et al., 2008) and a chemical transport model (the Global Modeling Initiative (GMI) combo-model driven by GEOS-4 meteorological fields (Strahan et al., 2007). In these model comparisons, the agreement between data sets is generally very good. When comparing the ACE-FTS and HALOE climatologies, we find similar biases as were found in the comparisons of coincident ACE-FTS and HALOE measurements, as reported in the ACE validation special issue (http://www. atmos-chem-phys.org/special_issue114.html). Also, we have compared our climatology results for $\mathrm{NO}_{2}$ to the combined model and measurement climatology produced by Brohede et al. (2008). These results are discussed below.

In addition, the ACE-FTS climatology has been compared with other satellite climatologies as part of the SPARC Data Initiative. The user is directed to the report from this initiative for additional comparisons and assessments (SPARC Data Initiative, in preparation).

\subsection{Monthly zonal mean climatologies}

$\mathrm{O}_{3}$ : Figure 4 shows the monthly climatological products for ozone in February and August (panels A and C) as well as the one sigma variability for the same months respectively (panels B and D). The VMR values at around $10 \mathrm{hPa}$ are typically greater than $10 \mathrm{ppmv}$ in the tropics, while values decrease gradually as one moves towards the polar latitudes. For these particular months, polar observations are only made in the winter. The stronger southern polar vortex (August) is more evident compared to the Northern Hemisphere polar vortex activity (February), which is more perturbed (and hence weaker) due to more frequent stratospheric sudden warmings. The estimates of ozone variation are based on one standard deviation of the VMR values for each grid bin. The largest variations are found close to the peak altitude in VMR in the extra-tropics and polar latitudes and are typically $0.5-1 \mathrm{ppmv}$. We can expect varying strengths of the polar vortex from year to year due to the relative timings of stratospheric warmings, hence we would expect to see the greatest variability in this region.

Large variations are occasionally seen at the limits of the grid, such as the highest and/or lowest altitudes. This is often due to a minimum number of measurements included in the climatological average. If the MAD filtering process has few 

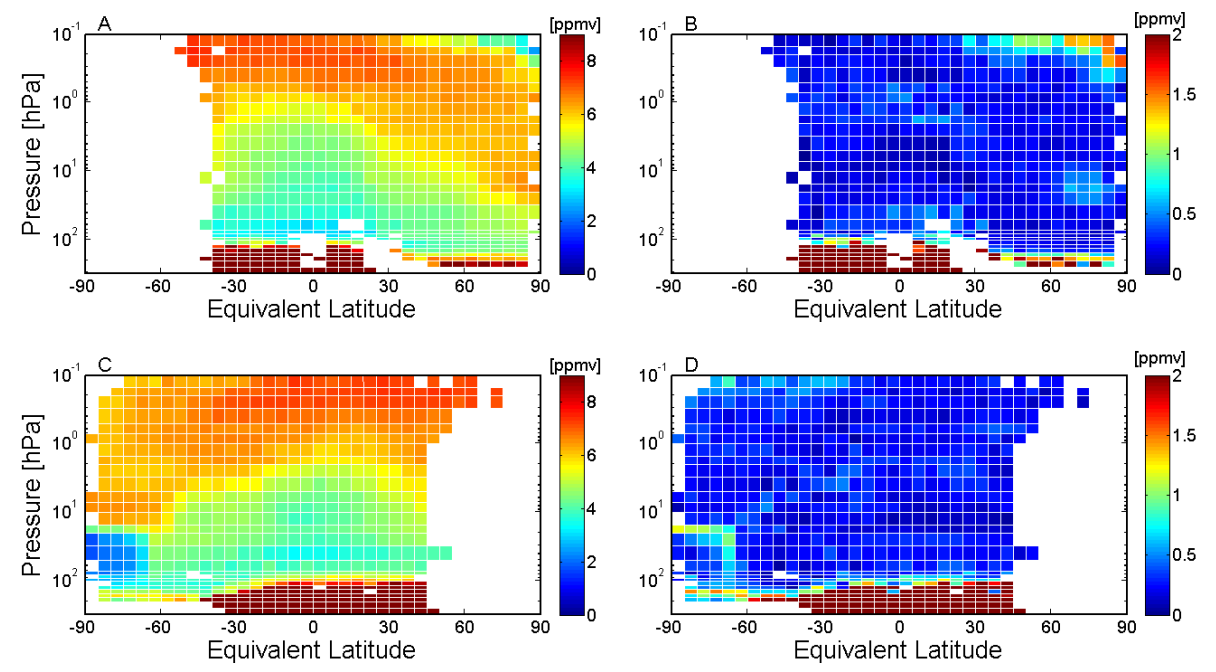

Fig. 5. Same as Fig. 4, but for $\mathrm{H}_{2} \mathrm{O}$.
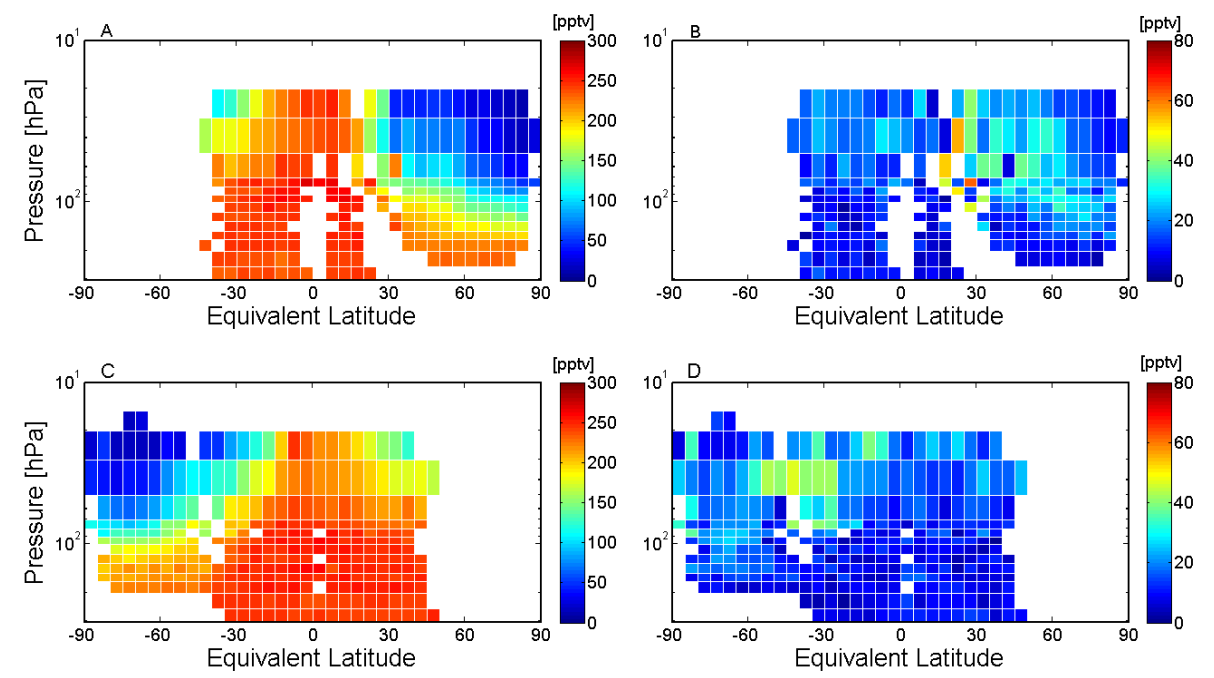

Fig. 6. Same as Fig. 4, but for $\mathrm{CCl}_{3} \mathrm{~F}$.

samples to consider then it may fail to remove (what would be considered otherwise) outliers. Although this may not affect the overall climatological VMR value for a given bin, it might well produce an unreliable variation value, due to the presence of an outlier(s). The total number of observations per grid cell can be used in these cases to determine the degree of statistical robustness.

$\mathrm{H}_{2} \mathrm{O}$ : Figure 5 illustrates the climatology for water vapour for February and August. The main photochemical source of water vapour in the stratosphere is the oxidation of $\mathrm{CH}_{4}$, hence a typical $\mathrm{H}_{2} \mathrm{O}$ profile is anti-correlated to a typical $\mathrm{CH}_{4}$ profile. Thus, VMRs increase with altitude throughout the stratosphere, yielding on average maximum values of 7-8 ppmv in the upper stratosphere in the tropics. The scale for the plots in Fig. 5 were chosen to best display the stratospheric and lower mesospheric results. Because the tro- pospheric concentrations of water vapour are significantly higher than those found in the stratosphere, the tropospheric mixing ratio values are off the scale in these plots. The very low water vapour values seen at high southern latitudes (August) are evidence of dehydration in the polar vortex. The one standard deviation climatological fields show the water vapour variation to be typically less than 0.4 ppmv throughout most of the stratosphere and lower mesosphere. Larger variation values (typically greater than $0.8 \mathrm{ppmv}$ ) are seen near polar latitudes and the mid-latitude/polar stratopause $(\sim 0.1 \mathrm{hPa})$ region.

$\mathrm{CCl}_{3} \mathrm{~F}$ : The ACE-FTS $\mathrm{CCl}_{3} \mathrm{~F}$ distribution in the middle/upper troposphere and lowermost stratosphere is shown in Fig. 6. The $\mathrm{CCl}_{3} \mathrm{~F}$ VMR values obtained range from 220 $300 \mathrm{ppbv}$ throughout the middle to upper troposphere. The VMR values start to decrease once it enters the stratosphere 

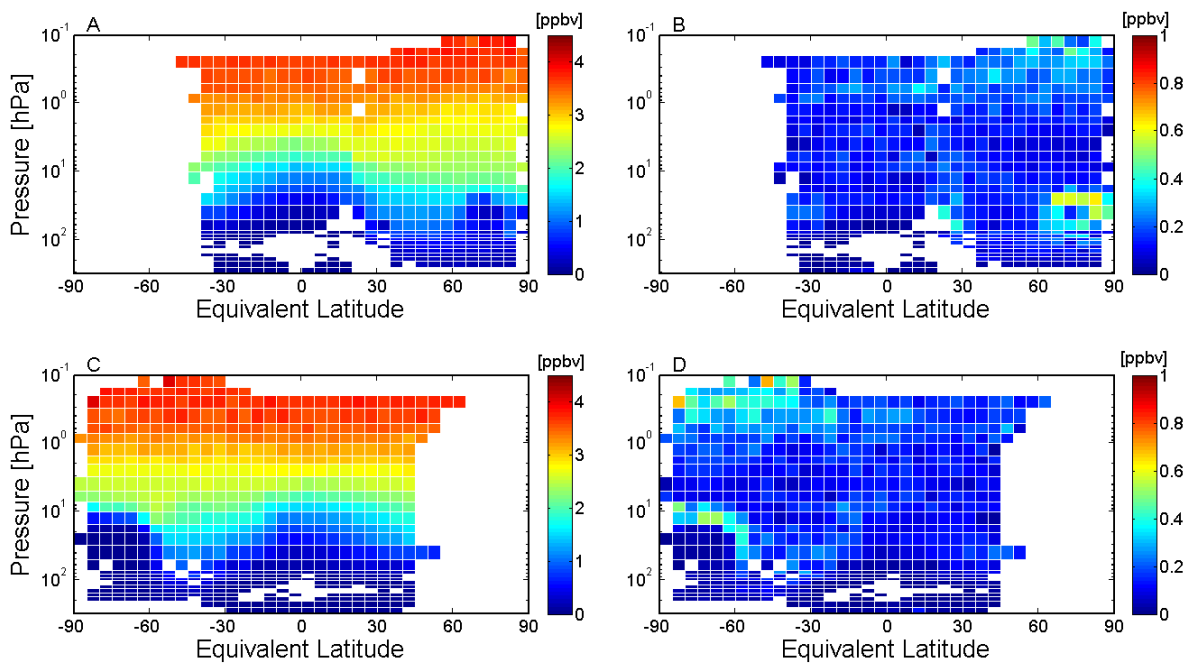

Fig. 7. Same as Fig. 4, but for $\mathrm{HCl}$.
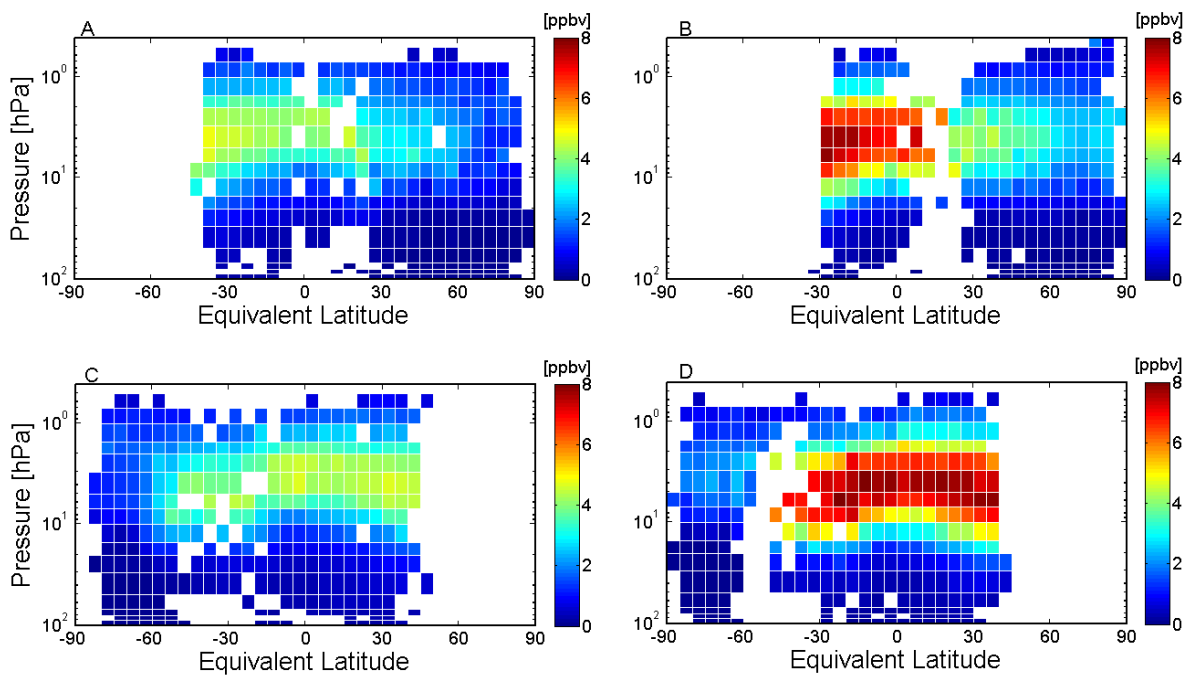

Fig. 8. $\mathrm{NO}_{2} \mathrm{AM}$ and PM climatologies for February (A) and (B) and August (C) and (D).

as $\mathrm{CCl}_{3} \mathrm{~F}$ is photolysed by intense UV radiation. The onesigma variation values are highest in the extra-tropics in the region just above the tropopause and on the order of $30 \mathrm{pptv}$. Otherwise, variation values are typically less than $20 \mathrm{pptv}$ in the troposphere and in the stratosphere.

$\mathrm{HCl}$ : Examples of the $\mathrm{HCl}$ climatology for February and August are given in Fig. 7. The stratospheric production of $\mathrm{HCl}$ is via the photolytic breakdown of CFCs, HCFCs, and chlorocarbons therefore $\mathrm{HCl}$ concentrations increase with altitude. $\mathrm{HCl}$ acts as a reservoir species outside of the polar regions, but it is converted to its reactive form $(\mathrm{ClO})$ through heterogeneous reactions on polar stratospheric clouds (PSCs) during the polar night. The breakdown of $\mathrm{HCl}$ is well represented by the low VMR values seen in the winter polar vortex region (below $30 \mathrm{hPa}$ ). Background variation values are generally less than $0.2 \mathrm{ppbv}$, but around the polar vor- tex, these variations are closer to $0.6 \mathrm{ppbv}$. The extra-tropical upper stratosphere also shows a tendency towards slightly higher variation values of about $0.4-0.5 \mathrm{ppb}$. This is likely to be related to a high bias found in the ACE-FTS $\mathrm{HCl}$ data at altitudes above $1 \mathrm{hPa}$. This bias has been reported in previous validation studies with MLS (Froidevaux et al., 2008).

$\mathrm{NO}$ and $\mathrm{NO}_{2}$ : Both $\mathrm{NO}_{2}$ and $\mathrm{NO}$, which form the $\mathrm{NO}_{\mathrm{x}}$ family, are active nitrogen species that are important for the catalytic ozone loss cycles in the stratosphere. Both of these species have strong diurnal variations, such that they are active during sunlit hours, but are quickly locked up into reservoir species such as $\mathrm{N}_{2} \mathrm{O}_{5}$ during the night. The strong diurnal variation of $\mathrm{NO}_{2}$ can be seen from Fig. 8. Here, observations have been separated into AM and PM based on the LST of the measurements. In both months, the PM observations ( $\sim 8 \mathrm{ppbv})$ are almost double that of the AM 

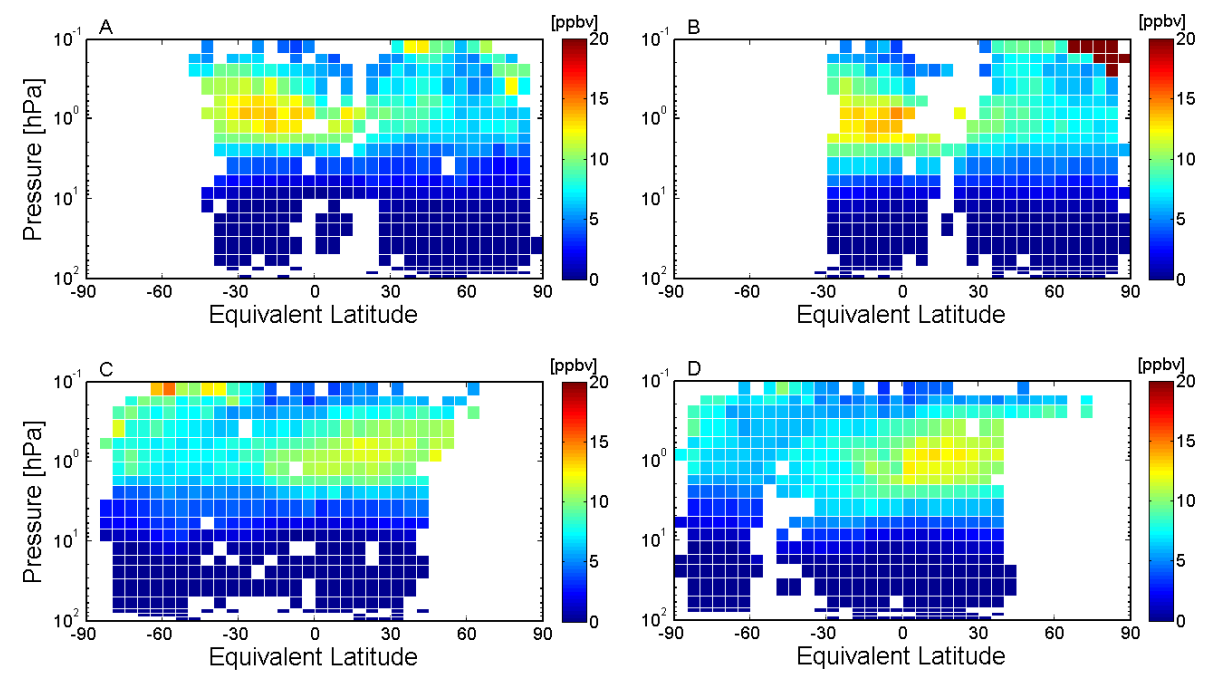

Fig. 9. Same as Fig. 8, but for NO.
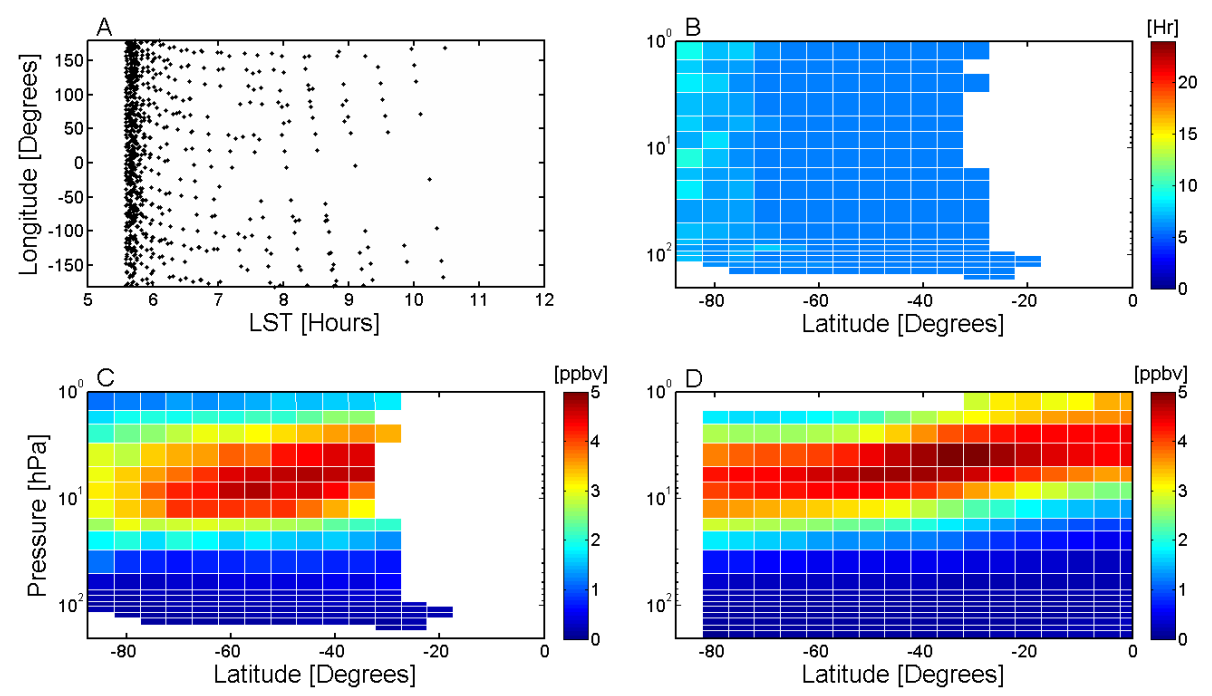

Fig. 10. Spread of LST for ACE-FTS AM observations during March (A). The median LST climatological field for March (B). The ACE $\mathrm{NO}_{2}$ March AM Climatology (C). The OSIRIS + model (Brohede et al., 2008) model $\mathrm{NO}_{2}$ climatology (2001-2008) (D).

observations ( $\sim 4 \mathrm{ppbv})$ in the tropical middle stratosphere, the region dominated by ozone chemistry. Figure 9 uses the same format as Fig. 8 to show the NO climatology. It can be seen that PM values are slightly higher than AM in the tropical middle stratosphere. Moreover, it is also apparent that large abundances of $\mathrm{NO}$ ( $>20 \mathrm{ppbv}$ ) are descending from the winter polar mesosphere to the stratosphere, particularly in the Northern Hemisphere. These are periods typically associated with solar energetic particle precipitation (EPP) (Funke et al., 2005; López-Puertas et al., 2005; Rinsland et al., 2005; Randall et al., 2005, 2006, 2007; Natarajan et al., 2004). Although the variation plots for $\mathrm{NO}$ and $\mathrm{NO}_{2}$ are not shown, we have found the values to vary widely (considering AM and PM independently), from typically less than 1 ppbv in the tropics to as large as $10-15$ ppbv in EPP influenced regions.

When using the climatologies for diurnally varying species, the LST must be considered. Figure 10, panel A shows how the LST of all March $\mathrm{NO}_{2} \mathrm{AM}$ measurements varies as a function of longitude. It should be noted that during March, AM occultations occur only in the Southern Hemisphere, while the PM occultations only occur in the Northern Hemisphere. It can be seen that most of the AM occultations occur at approximately 05:00-06:00 a.m. Panel B presents the resulting median LST for each grid box based on these measurements. In the tropics and midlatitudes, each climatological value has a median LST close to 05:00-06:00 a.m. while the median LST values in the 

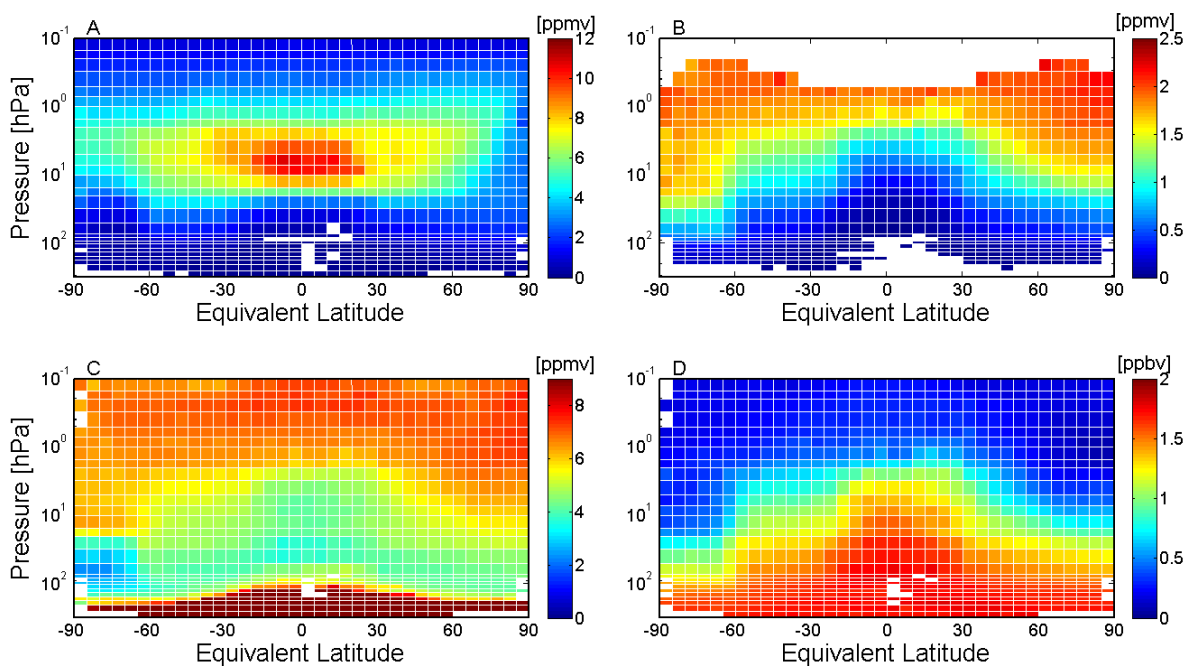

Fig. 11. ACE-FTS three-month combined climatologies (September-October-November ( $\mathrm{SON})$ for $\mathrm{O}_{3}(\mathbf{A})$, for $\mathrm{HF}(\mathbf{B})$, for $\mathrm{H}_{2} \mathrm{O}(\mathbf{C})$, and for $\mathrm{CH}_{4}$ (D).

polar latitudes are closer to 09:00 a.m. The $\mathrm{NO}_{2} \mathrm{AM}$ climatology is exhibited in panel $\mathrm{C}$. We now compare the ACE-FTS $\mathrm{NO}_{2}$ zonal average to the climatology produced by Brohede et al. (2008), who incorporated Optical Spectrograph InfraRed Imager System (OSIRIS) measurements and results from a photochemical box model. Panel D shows the OSIRIS + model climatology data for March (20012008) computed for a LST of 6 AM. Comparing panels $\mathrm{C}$ and $\mathrm{D}$, there is a good agreement between ACE-FTS and OSIRIS + model in terms of structure and VMR values. Here, differences in $\mathrm{NO}_{2}$ VMRs between ACE-FTS and OSIRIS + model are typically less than $1 \mathrm{ppbv}$, which is similar to the magnitude of bias reported in the Kerzenmacher et al. (2008) validation analysis for coincident ACE-FTS and Odin OSIRIS $\mathrm{NO}_{2}$ profiles.

\subsection{The 3 month combined zonal averages}

Figure 11 shows an example of three-month combined zonal averages for four different species: panel A shows $\mathrm{O}_{3}$, panel B shows HF, panel C shows $\mathrm{H}_{2} \mathrm{O}$, and panel D shows $\mathrm{CH}_{4}$ during September-October-November (SON).

We can see that by using this methodology we can obtain an excellent coverage from pole to pole for these four cases. Some examples of interesting features are in panel A where there is evidence for ozone depletion in the Southern Hemisphere polar vortex, while panel C illustrates nicely the dehydration of water vapour in the Southern Hemisphere polar vortex. Comparison of panels $\mathrm{C}$ and $\mathrm{D}$ show the anticorrelated behaviour of $\mathrm{H}_{2} \mathrm{O}$ and $\mathrm{CH}_{4}$, where $\mathrm{CH}_{4}$ is oxidized to $\mathrm{H}_{2} \mathrm{O}$ as one moves up through the atmosphere. Panel B illustrates evidence of vertical descent of enhanced HF VMRs ( 2-2.2 ppbv) from the mesospheric southern polar latitudes into the stratospheric polar region, where HF
VMRs are less $(\sim 1.5-1.7 \mathrm{ppbv})$. Finally, there is also evidence for strong horizontal mixing in the southern extra tropics (below $\sim 3 \mathrm{hPa}$ ) seen in panel $\mathrm{B}, \mathrm{D}$, and to a lesser degree in panel $\mathrm{C}$.

\section{Summary}

ACE-FTS profiles from the version 2.2 (plus updates for $\mathrm{O}_{3}$ and $\mathrm{N}_{2} \mathrm{O}_{5}$ ) data set have been utilized to produce multi-year (2004-2009) zonal average climatologies for 14 atmospheric species. Monthly and combined three-month (DJF, MAM, JJA, SON) climatologies are produced on a vertical pressure grid and as a function of latitude or equivalent latitude. The ACE-FTS climatological data set contains: $\mathrm{O}_{3}, \mathrm{H}_{2} \mathrm{O}, \mathrm{CH}_{4}$, $\mathrm{N}_{2} \mathrm{O}, \mathrm{CO}, \mathrm{NO}, \mathrm{NO}_{2}, \mathrm{~N}_{2} \mathrm{O}_{5}, \mathrm{HNO}_{3}, \mathrm{HCl}, \mathrm{ClONO}_{2}, \mathrm{CCl}_{3} \mathrm{~F}$, $\mathrm{CCl}_{2} \mathrm{~F}_{2}$, and HF. A statistical technique using the median average deviation (MAD) has been employed to eliminate outliers effectively from the data set. The data quality of the retrievals (given by the inverse of the fitting error) is used to weight the values used in the climatological averages. This ACE-FTS climatology will be an excellent complement to the current climatological data sets based on measurements from other satellite missions and ozonesondes by providing data for a wider number of species in a consistent data set. These climatological products will provide a source of data for model intercomparison studies and other atmospheric research projects, including the SPARC initiative to evaluate climatological data sets obtained from satellite instruments (SPARC Data Initiative, in preparation).

Supplementary material related to this article is available online at: http://www.atmos-chem-phys.net/12/ 5207/2012/acp-12-5207-2012-supplement.zip. 
Acknowledgements. The Atmospheric Chemistry Experiment (ACE), also known as SCISAT, is a Canadian-led mission mainly supported by the Canadian Space Agency (CSA) and the Natural Sciences and Engineering Research Council of Canada (NSERC). This work was supported by grants from the Canadian Foundation for Climate and Atmospheric Science (CFCAS) and CSA. Work at the Jet Propulsion Laboratory, California Institute of Technology is done under contract with the National Aeronautics and Space Administration. Some support is also provided by the UK Natural Environment Research Council, NERC.

Edited by: M. Dameris

\section{References}

Beaver, G. M. and Russell, J. M.: The climatology of stratospheric $\mathrm{HCl}$ and HF observed by HALOE, Adv. Space Res., 21, 13731382, 1998.

Bernath, P. F., McElroy, C. T., Abrams, M. C., Boone, C. D., Butler, M., Camy-Peyret, C., Carleer, M., Clerbaux, C., Coheur, P. F., Colin, R., DeCola, P., Mazière, M. D., Drummond, J. R., Dufour, D., Evans, W. F. J., Fast, H., Fussen, D., Gilbert, K., Jennings, D. E., Llewellyn, E. J., Lowe, R. P., Mahieu, E., McConnell, J. C., McHugh, M., McLeod, S. D., Michaud, R., Midwinter, C., Nassar, R., Nichitu, F., Nowlan, C., Rinsland, C. P., Rochon, Y. J., Rowlands, N., Semeniuk, K., Simon, P., Skelton, R., Sloan, J. J., Soucy, M. A., Strong, K., Tremblay, P., Turnbull, D., Walker, K. A., Walkty, I., Wardle, D. A., Wehrle, V., Zander, R., and Zou, J.: Atmospheric Chemistry Experiment (ACE): Mission overview, Geophys. Res. Lett., 32, L15S01, doi:10.1029/2005GL022386, 2005.

Boone, C. D., Nassar, R., Walker, K. A., Rochon, Y. J., McLeod, S. D., Rinsland, C. P., and Bernath, P. F.: Retrievals for the Atmospheric Chemistry Experiment Fourier-Transform Spectrometer, Appl. Optics, 44, 7218-7231, 2005.

Brohede, S., McLinden, C. A., Urban, J., Haley, C. S., Jonsson, A. I., and Murtagh, D.: Odin stratospheric proxy $\mathrm{NO}_{\mathrm{y}}$ measurements and climatology, Atmos. Chem. Phys., 8, 5731-5754, doi:10.5194/acp-8-5731-2008, 2008.

Butchart, N. and Remsberg, E. E.: The area of the stratospheric polar vortex as a diagnostic for tracer transport on an isentropic surface, J. Atmos. Sci., 43, 1319-1339, 1986.

Carleer, M. R., Boone, C. D., Walker, K. A., Bernath, P. F., Strong, K., Sica, R. J., Randall, C. E., Vömel, H., Kar, J., Höpfner, M., Milz, M., von Clarmann, T., Kivi, R., Valverde-Canossa, J., Sioris, C. E., Izawa, M. R. M., Dupuy, E., McElroy, C. T., Drummond, J. R., Nowlan, C. R., Zou, J., Nichitiu, F., Lossow, S., Urban, J., Murtagh, D., and Dufour, D. G.: Validation of water vapour profiles from the Atmospheric Chemistry Experiment (ACE), Atmos. Chem. Phys. Discuss., 8, 4499-4559, doi:10.5194/acpd-8-4499-2008, 2008.

Chiou, E. W., McCormick, M., and Chu, W. P.: Global water vapor distributions in the stratosphere and upper troposphere derived from 5.5 years of SAGE II observations (1986-1991), J. Geophys. Res., 102, 19105-19118, 1997.

Clerbaux, C., George, M., Turquety, S., Walker, K. A., Barret, B., Bernath, P., Boone, C., Borsdorff, T., Cammas, J. P., Catoire, V.,
Coffey, M., Coheur, P.-F., Deeter, M., De Mazière, M., Drummond, J., Duchatelet, P., Dupuy, E., de Zafra, R., Eddounia, F., Edwards, D. P., Emmons, L., Funke, B., Gille, J., Griffith, D. W. T., Hannigan, J., Hase, F., Höpfner, M., Jones, N., Kagawa, A., Kasai, Y., Kramer, I., Le Flochmoën, E., Livesey, N. J., López-Puertas, M., Luo, M., Mahieu, E., Murtagh, D., Nédélec, P., Pazmino, A., Pumphrey, H., Ricaud, P., Rinsland, C. P., Robert, C., Schneider, M., Senten, C., Stiller, G., Strandberg, A., Strong, K., Sussmann, R., Thouret, V., Urban, J., and Wiacek, A.: CO measurements from the ACE-FTS satellite instrument: data analysis and validation using ground-based, airborne and spaceborne observations, Atmos. Chem. Phys., 8, 2569-2594, doi:10.5194/acp-8-2569-2008, 2008.

Dupuy, E., Walker, K. A., Kar, J., Boone, C. D., McElroy, C. T., Bernath, P. F., Drummond, J. R., Skelton, R., McLeod, S. D., Hughes, R. C., Nowlan, C. R., Dufour, D. G., Zou, J., Nichitiu, F., Strong, K., Baron, P., Bevilacqua, R. M., Blumenstock, T., Bodeker, G. E., Borsdorff, T., Bourassa, A. E., Bovensmann, H., Boyd, I. S., Bracher, A., Brogniez, C., Burrows, J. P., Catoire, V., Ceccherini, S., Chabrillat, S., Christensen, T., Coffey, M. T., Cortesi, U., Davies, J., De Clercq, C., Degenstein, D. A., De Mazière, M., Demoulin, P., Dodion, J., Firanski, B., Fischer, H., Forbes, G., Froidevaux, L., Fussen, D., Gerard, P., Godin-Beekmann, S., Goutail, F., Granville, J., Griffith, D., Haley, C. S., Hannigan, J. W., Höpfner, M., Jin, J. J., Jones, A., Jones, N. B., Jucks, K., Kagawa, A., Kasai, Y., Kerzenmacher, T. E., Kleinböhl, A., Klekociuk, A. R., Kramer, I., Küllmann, H., Kuttippurath, J., Kyrölä, E., Lambert, J.-C., Livesey, N. J., Llewellyn, E. J., Lloyd, N. D., Mahieu, E., Manney, G. L., Marshall, B. T., McConnell, J. C., McCormick, M. P., McDermid, I. S., McHugh, M., McLinden, C. A., Mellqvist, J., Mizutani, K., Murayama, Y., Murtagh, D. P., Oelhaf, H., Parrish, A., Petelina, S. V., Piccolo, C., Pommereau, J.-P., Randall, C. E., Robert, C., Roth, C., Schneider, M., Senten, C., Steck, T., Strandberg, A., Strawbridge, K. B., Sussmann, R., Swart, D. P. J., Tarasick, D. W., Taylor, J. R., Tétard, C., Thomason, L. W., Thompson, A. M., Tully, M. B., Urban, J., Vanhellemont, F., Vigouroux, C., von Clarmann, T., von der Gathen, P., von Savigny, C., Waters, J. W., Witte, J. C., Wolff, M., and Zawodny, J. M.: Validation of ozone measurements from the Atmospheric Chemistry Experiment (ACE), Atmos. Chem. Phys., 9, 287-343, doi:10.5194/acp9-287-2009, 2009.

Fortuin, J. P. F. and Kelder, H.: An ozone climatology based on ozonesonde and satellite measurements, J. Geophys. Res., 103, 31709-31734, 1998.

Froidevaux, L., Jiang, Y. B., Lambert, A., Livesey, N. J., Read, W. G., Waters, J. W., Fuller, R. A., Marcy, T. P., Popp, P. J., Gao, R. S., Fahey, D. W., Jucks, K. W., Stachnik, R. A., Toon, G. C., Christensen, L .E., Webster, C. R., Bernath, P .F., Boone, C. D., Walker, K. A., Pumphrey, H. C., Harwood, R. S., Manney, G. L., Schwartz, M. J., Daffer, W. H., Drouin, B. J., Cofield, R. E., Cuddy, D. T., Jarnot, R. F., Knosp, B. W., Perun, V. S., Snyder, W. V., Stek, P. C., Thurstans, R. P. and Wagner, P. A.: Validation of Aura Microwave Limb Sounder $\mathrm{HCl}$ measurements, J. Geophys. Res., 113, D15S25, doi:10.1029/2007JD009025, 2008.

Funke, B., López-Puertas, M., Gil-Lòpez, S., von Clarmann, T., Stiller, G. P., Fischer, H., and Kellmann, S.: Downward transport of upper atmospheric NOx into the polar stratosphere and lower mesosphere during the Antarctic 2003 and 
Arctic 2002/2003 winters, J. Geophys. Res., 110, D09308, doi:10.1029/2005JD006463, 2005.

Gilbert, K.L.,Turnbull, D. N., Walker, K. A., Boone, C. D., McLeod, S. D., Butler, M., Skelton, R., Bernath, P. F., Chateauneuf, F., and Soucy, M. A.: The onboard imagers for the Canadian ACE SCISAT-1 mission, J. Geophys. Res., 112, D12207, doi:10.1029/2006JD007714, 2007.

Grooß, J.-U. and Russell III, J. M.: Technical note: A stratospheric climatology for $\mathrm{O}_{3}, \mathrm{H}_{2} \mathrm{O}, \mathrm{CH}_{4}, \mathrm{NO}_{\mathrm{x}}, \mathrm{HCl}$ and $\mathrm{HF}$ derived from HALOE measurements, Atmos. Chem. Phys., 5, 2797-2807, doi:10.5194/acp-5-2797-2005, 2005.

Hoffmann, L., Kaufmann, M., Spang, R., Muller, R., Remedios, J. J., Moore, C., Volk, M., and von Clarmann, T.: Envisat MIPAS measurements of CFC-11: retrieval, validation, and climatology, Atmos. Chem. Phys., 8, 3671-3688, 2008,

http://www.atmos-chem-phys.net/8/3671/2008/.

Huber, P.: Robust Statistics, Wiley, New York, 2004.

Jones, A., Qin, G., Strong, K., Walker, K. A., McLinden, C. A., Toohey, M., Kerzenmacher, T., Bernath, P. F., and Boone, C. D.: A global inventory of stratospheric $\mathrm{NO}_{\mathrm{y}}$ from ACE-FTS, J. Geophys. Res., 116, D17304, doi:10.1029/2010JD015465, 2011.

Kerzenmacher, T., Wolff, M. A., Strong, K., Dupuy, E., Walker, K. A., Amekudzi, L. K., Batchelor, R. L., Bernath, P. F., Berthet, G., Blumenstock, T., Boone, C. D., Bramstedt, K., Brogniez, C., Brohede, S., Burrows, J. P., Catoire, V., Dodion, J., Drummond, J. R., Dufour, D. G., Funke, B., Fussen, D., Goutail, F., Griffith, D. W. T., Haley, C. S., Hendrick, F., Höpfner, M., Huret, N., Jones, N., Kar, J., Kramer, I., Llewellyn, E. J., López-Puertas, M., Manney, G., McElroy, C. T., McLinden, C. A., Melo, S., Mikuteit, S., Murtagh, D., Nichitiu, F., Notholt, J., Nowlan, C., Piccolo, C., Pommereau, J.-P., Randall, C., Raspollini, P., Ridolfi, M., Richter, A., Schneider, M., Schrems, O., Silicani, M., Stiller, G. P., Taylor, J., Tétard, C., Toohey, M., Vanhellemont, F., Warneke, T., Zawodny, J. M., and Zou, J.: Validation of $\mathrm{NO}_{2}$ and NO from the Atmospheric Chemistry Experiment (ACE), Atmos. Chem. Phys., 8, 5801-5841, doi:10.5194/acp-8-5801-2008, 2008

Kouker, W., Langbein, I., Reddmann, T., and Ruhnke, R.: The Karlsruhe simulation model of the middle atmosphere (KASIMA), version 2, 6278, FZKA Wissenschaftliche Berichte - Scientific Reports, Forschungszentrum Karlsruhe, 1999.

López-Puertas, M., Funke, B., Gil-López, S., Von Clarmann, T., Stiller, G. P., Höpfner, M., Kellman, S., Fischer, H., and Jackman, C. H.: Observation of $\mathrm{NO}_{\mathrm{x}}$ enhancement and ozone depletion in the Northern and Southern Hemispheres after the October-November 2003 solar proton events, J. Geophys. Res., 110, A09S43, doi:10.1029/2005JA011050, 2005.

Mahieu, E., Duchatelet, P., Demoulin, P., Walker, K. A., Dupuy, E., Froidevaux, L., Randall, C., Catoire, V., Strong, K., Boone, C. D., Bernath, P. F., Blavier, J.-F., Blumenstock, T., Coffey, M., De Mazière, M., Griffith, D., Hannigan, J., Hase, F., Jones, N., Jucks, K. W., Kagawa, A., Kasai, Y., Mebarki, Y., Mikuteit, S., Nassar, R., Notholt, J., Rinsland, C. P., Robert, C., Schrems, O., Senten, C., Smale, D., Taylor, J., Tétard, C., Toon, G. C., Warneke, T., Wood, S. W., Zander, R., and Servais, C.: Validation of ACEFTS v2.2 measurements of $\mathrm{HCl}, \mathrm{HF}, \mathrm{CCl}_{3} \mathrm{~F}$ and $\mathrm{CCl}_{2} \mathrm{~F}_{2}$ using space-, balloon- and ground-based instrument observations, Atmos. Chem. Phys., 8, 6199-6221, doi:10.5194/acp-8-6199-2008, 2008.
Manney, G. L., Daffer, W. H., Zawodny, J. M., Bernath, P. F., Hoppel, K. W., Walker, K. A., Knosp, B. W., Boone, C., Remsberg, E. E., Santee, M. L., Lynn Harvey, V., Pawson, S., Jackson, D. R., Deaver, L., McElroy, C. T., McLinden, C. A., Drummond, J. A., Pumphrey, H. C., Lambert, A., Schwartz, M. J., Froidevaux, L., McLeod, S., Takacs, L. L., Suarez, M. J., Trepte, C. R., Cuddy, D. T., Livesey, N. J., Harwood, R. S., and Waters, J. W.: Solar Occultation Satellite Data and Derived Meteorological Products: Sampling Issues and Comparisons with Aura MLS, J. Geophys. Res., 112, D24S50, doi:10.1029/2007JD008709, 2007.

De Mazière, M., Vigouroux, C., Bernath, P. F., Baron, P., Blumenstock, T., Boone, C., Brogniez, C., Catoire, V., Coffey, M., Duchatelet, P., Griffith, D., Hannigan, J., Kasai, Y., Kramer, I., Jones, N., Mahieu, E., Manney, G. L., Piccolo, C., Randall, C., Robert, C., Senten, C., Strong, K., Taylor, J., Tétard, C., Walker, K. A., and Wood, S.: Validation of ACE-FTS v2.2 methane profiles from the upper troposphere to the lower mesosphere, Atmos. Chem. Phys., 8, 2421-2435, doi:10.5194/acp-8-2421-2008, 2008.

McElroy, C. T., Nowlan, C. R., Drummond, J. R., Bernath, P. F., Barton, D. V., Dufour, D. G., Midwinter, C., Hall, R. B., Ogyu, A., Ullberg, A., Wardle, D. I., Kar, J., Zou, J., Nichitiu, F., Boone, C. D., Walker, K. A., and Rowlands, N.: The ACE-MAESTRO instrument on SCISAT: Description, performance, and preliminary results, Appl. Optics, 46, 4341-4356, 2007.

McLinden, C. A., Olsen, S. C., Hannegan, B., Wild, O., Prather, M. J., and Sundet, J.: Stratospheric ozone in 3-D models: A simple chemistry and the cross-tropopause flux, J. Geophys. Res., 105, 14653-14665, 2000.

McLinden, C. A., Haley, C. S., and Sioris, C. E.: Diurnal effects in limb scatter observations, J. Geophys. Res., 111, D14302, doi:10.1029/2005JD006628, 2006.

McPeters, R. D., Labow, G. J., and Logan, J. A.: Ozone climatological profiles for satellite retrieval algorithms, J. Geosphys Res., 112, D05308, doi:10.1029/2005JD006823, 2007.

Nassar, R., Bernath, P. F., Boone, C. D., McLeod, S. D., Skelton, R., Walker, K. A., Rinsland, C. P., and Duchatelet, P.: A global inventory of stratospheric fluorine in 2004 based on Atmospheric Chemistry Experiment Fourier transform spectrometer (ACE-FTS) measurements, J. Geophys. Res., 111, D22313, doi:10.1029/2006JD007395, 2006.

Natarajan, M., Remsberg, E. E., Deaver, E. E., and Russell III, J. M.: Anomalously high levels of $\mathrm{NO}_{\mathrm{x}}$ in the polar upper stratosphere during Apr, 2004: Photochemical consistency of HALOE observations, Geophys. Res. Lett. 31, L15113, doi:10.1029/2004GL020566, 2004.

Randall, C. E., Harvey, V. L., Manney, G. L., Orsolini, Y., Codrescu, M., Sioris, C., Brohede, S., Haley, C. S., Gordley, L. L., Zawodny, J. M., and Russell, J. M.: Stratospheric effects of energetic particle precipitation in 2003-2004, Geophys. Res. Lett., 32, L05802, doi:10.1029/2004GL022003, 2005.

Randall, C. E., Harvey, V. L., Singleton, C. S., Bernath, P. F., Boone, C. D., and Kozyra, J. U.: Enhanced $\mathrm{NO}_{\mathrm{x}}$ in 2006 linked to strong upper stratospheric Arctic vortex, Geophys. Res. Lett., 33, L18811, doi:10.1029/2006GL027160, 2006.

Randall, C. E., Harvey, V. L., Singleton, C. S., Bailey, S. M., Bernath, P. F., Codrescu, M., Nakajima, H., Russell III, J. M.: Energetic particle precipitation effects on the Southern Hemisphere stratosphere in 1992-2005, J. Geophys. Res., 112, D08308, 
doi:10.1029/2006JD007696, 2007.

Randel, W. J., Wu, F., Russell, J. M., Roche, A., and Waters, J. W.: Seasonal cycles and QBO variations in stratospheric $\mathrm{CH}_{4}$ and $\mathrm{H}_{2} \mathrm{O}$ observed in UARS HALOE data, J. Atmos. Sci., 55, 163185, 1998.

Rienecker, M. M., Suarez, M. J., Todling, R., Bacmeister, J., Takacs, L., Liu, H.-C., Gu, W., Sienkiewicz, M., Koster, R. D., Gelaro, R., Stajner, I., and Nielsen, J. E.: The GEOS-5 Data Assimilation System - Documentation of Versions 5.0.1, 5.1.0, and 5.2.0, Technical Report Series on Global Modeling and Data Assimilation, 27, 2008.

Rinsland, C. P., Boone, C., Nassar, R., Walker, K., Bernath, P., McConnell, J. C., and Chiou, L.: Atmospheric Chemistry Experiment (ACE) Arctic stratospheric measurements of $\mathrm{NO}_{\mathrm{x}}$ during February and March 2004: Impact of intense solar flares, Geophys. Res. Lett., 32, L16S05, doi:10.1029/2005GL022425, 2005.

Rothman, L. S., Jacquemart, D., Barbe, A., Chris Bennerc, D., Birk, M., Brown, L. R., Carleer, M. R., Chackerian Jr., C., Chance, K., Coudert, L. H., Dana, V., Devi, V. M., Flaud, J.-M., Gamache, R. R., Goldman, A., Hartmann, J.-M., Jucks, K. W., Maki, A. G., Mandin, J.-Y., Massie, S. T., Orphal, J., Perrin, A., Rinsland, C. P., Smith, M. A. H., Tennyson, J., Tolchenov, R. N., Toth, R. A., Vander Auwera, J., Varanasi, P., and Wagner, G.: The HITRAN 2004 molecular spectroscopic database, J. Quant. Spectrosc. Ra., 96, 139-204, 2005.

Russell, J. M., Gordley, L. L., Park, J. H., Drayson, S. R., Tuck, A. F., Harries, J. E., Cicerone, R. J., Crutzen, P. J., and Frederick, J. E.: The Halogen Occultation Experiment, J. Geophys. Res., 98, 10777-10797, 1993.

Scinocca, J. F., McFarlane, N. A., Lazare, M., Li, J., and Plummer, D.: Technical Note: The CCCma third generation AGCM and its extension into the middle atmosphere, Atmos. Chem. Phys., 8, 7055-7074, doi:10.5194/acp-8-7055-2008, 2008.

SPARC CCMVal, SPARC Report on the Evaluation of ChemistryClimate Models, edited by: Eyring, V., Shepherd, T. G., and Waugh, D. W., SPARC Report No. 5, WCRP-132, WMO/TDNo. 1526, 2010.

SPARC Data Initiative, SPARC Data Initiative Report, edited by: Hegglin, M. I. and Tegtmeier, S., SPARC Report No. 6, in preparation.
Strong, K., Wolff, M. A., Kerzenmacher, T. E., Walker, K. A., Bernath, P. F., Blumenstock, T., Boone, C., Catoire, V., Coffey, M., De Mazière, M., Demoulin, P., Duchatelet, P., Dupuy, E., Hannigan, J., Höpfner, M., Glatthor, N., Griffith, D. W. T., Jin, J. J., Jones, N., Jucks, K., Kuellmann, H., Kuttippurath, J., Lambert, A., Mahieu, E., McConnell, J. C., Mellqvist, J., Mikuteit, S., Murtagh, D. P., Notholt, J., Piccolo, C., Raspollini, P., Ridolfi, M., Robert, C., Schneider, M., Schrems, O., Semeniuk, K., Senten, C., Stiller, G. P., Strandberg, A., Taylor, J., Tétard, C., Toohey, M., Urban, J., Warneke, T., and Wood, S.: Validation of ACE-FTS $\mathrm{N}_{2} \mathrm{O}$ measurements, Atmos. Chem. Phys., 8, 47594786, doi:10.5194/acp-8-4759-2008, 2008.

Strahan, S. E., Duncan, B. N., and Hoor, P.: Observationally derived transport diagnostics for the lowermost stratosphere and their application to the GMI chemistry and transport model, Atmos. Chem. Phys., 7, 2435-2445, doi:10.5194/acp-7-2435-2007, 2007.

Toohey, M., Strong, K., Bernath, P. F., Boone, C. D., Walker, K. A., Jonsson, A. I., and Shepherd, T. G.: Validating the reported random errors of ACE?FTS measurements, J. Geophys. Res., 115, D20304, doi:10.1029/2010JD014185, 2010.

Urban, J., Pommier, M., Murtagh, D. P., Santee, M. L., and Orsolini, Y. J.: Nitric acid in the stratosphere based on Odin observations from 2001 to 2009 - Part 1: A global climatology, Atmos. Chem. Phys., 9, 7031-7044, doi:10.5194/acp-9-7031-2009, 2009.

Wolff, M. A., Kerzenmacher, T., Strong, K., Walker, K. A., Toohey, M., Dupuy, E., Bernath, P. F., Boone, C. D., Brohede, S., Catoire, V., von Clarmann, T., Coffey, M., Daffer, W. H., De Mazière, M., Duchatelet, P., Glatthor, N., Griffith, D. W. T., Hannigan, J., Hase, F., Höpfner, M., Huret, N., Jones, N., Jucks, K., Kagawa, A., Kasai, Y., Kramer, I., Küllmann, H., Kuttippurath, J., Mahieu, E., Manney, G., McElroy, C. T., McLinden, C., Mébarki, Y., Mikuteit, S., Murtagh, D., Piccolo, C., Raspollini, P., Ridolfi, M., Ruhnke, R., Santee, M., Senten, C., Smale, D., Tétard, C., Urban, J., and Wood, S.: Validation of $\mathrm{HNO}_{3}, \mathrm{ClONO}_{2}$, and $\mathrm{N}_{2} \mathrm{O}_{5}$ from the Atmospheric Chemistry Experiment Fourier Transform Spectrometer (ACE-FTS), Atmos. Chem. Phys., 8, 3529-3562, doi:10.5194/acp-8-3529-2008, 2008. 